\title{
Drug Repurposing and Dosage Form Development of Anti-COVID-19
}

\author{
Kevin Kwok \\ Faculty of Pharmacy, Universitas Indonesia, Depok, West Java, Indonesia
}

\begin{abstract}
The COVID-19 pandemic has been occurring approximately for more than 1 year. This pandemic has been a health issue that hits all countries in the world caused by the transmission of SARS$\mathrm{CoV}-2$ virus from one individual to another. The symptoms showed from the infected are fever, shortness of breath, dry cough, headache, and sore throat, among others. The SARS-CoV-2 virus is transmitted through sneezing, coughing, talking, and touching infected objects. Along with this transmission, the SARS-CoV-2 virus will continue to mutate. This mutation becomes an obstacle as well as a challenge to find drugs that can overcome the SARS-CoV-2 virus effectively and safely. The drugs used as anti-COVID-19 are still limited. The steps taken in the process of discovering and developing anti-COVID-19 drugs were through the drug repurposing approach because of the advantages it provides, such as shortens the duration and minimizes the costs required. After several drugs that have potential as anti-COVID-19 were obtained, further research on the development of dosage forms and formulas was carried out to obtain more effective and safer antiCOVID-19 drugs. This review aims to discuss several drugs gained from drug repurposing that have the potential as anti-COVID-19 drugs such as remdesivir, chloroquine/hydroxychloroquine, azithromycin, corticosteroids, and other potential drugs. This review will also discuss several developments of dosage form from the repurposed drugs.
\end{abstract}

Keywords: COVID-19; anti-COVID-19 drugs; drug repurposing; dosage form development

*corresponding author

Email:kevin.kwok@ui.ac.id

\section{INTRODUCTION}

The COVID-19 pandemic is a current global health issue with rapid transmission between individuals by the SARS-CoV-2 virus. This virus is a new type of betacoronavirus from the coronaviridae family and is responsible for infectious diseases of the respiratory tract, gastrointestinal tract, liver, and nervous system in mammals, besides alphacoronavirus (Sheikhzadeh et al., 2020; Ye et al., 2020). The name of this virus is derived from Latin word "corona" which means 'crown' because this virus has a crown-like shape which is formed from the spike protein on the surface of its cell when viewed with a microscope (Sharma et al., 2020). Two thirds of the genomic structure of the SARS-CoV-2 virus is RNA polymerase which has a function to encode the synthesis of RNA and large polyproteins that are not involved in modulating the host response, while another third is genes that encode the 4 types of structural proteins such as spike (S), envelope (E), membrane (M), and nucleocapsid (N) (Sheikhzadeh et al., 2020). In addition, the SARS-CoV-2 virus has a nucleotide with $78 \%$ similarity to the SARS virus and $50 \%$ to the MERS virus, but SARS-CoV-2 has faster transmission rate than those two viruses (Sheikhzadeh et al., 2020; Yang et al., 2020).

The SARS-CoV-2 virus can be transmitted from one individual to another directly or indirectly. The direct transmission of the SARS-CoV-2 virus is through droplets of body fluids from the respiratory tract when an infected person coughs, sneezes, or talks. On the other hand, the transmission of this virus indirectly occurs when a person touches other individuals or objects that have been contaminated and subsequently touches own mucous membranes such as eyes, mouth, or nose (Lotfi et al., 2020; Sharma et al., 2020). After being infected with the virus, the patient will show common symptoms such as fever, dry cough, shortness of breath, sore throat, headache, nasal congestion, sneezing, fatigue, and muscle aches (Hui et al., 2020; Lotfi et al., 2020; Sharma et al., 2020). The worst repercussion of the infection is death. The reason of these mortalities is suspected to be a condition called "cytokine storm" or "cytokine storm syndrome (CSS)" or "cytokine release syndrome (CRS)" (Behrens \& Koretzky, 2017). Cytokine storm is a condition in which innate and adaptive immune response, such as tumor necrosis factor- $\alpha$ (TNF- $\alpha$ ), interleukin (IL)-1 $\beta$, IL-2, IL-6, IL-8, IL-10, interferon- $\gamma$, granulocyte colony-stimulating factor, and many other cytokines are uncontrollable which can lead to apoptosis of epithelial cells and endothelial cells, vascular leakage and even death (Channappanavar \& Perlman, 2017; Lee et al., 2015). Many studies also showed that on severe conditions of COVID-19, it tended to have higher concentration of cytokine, especially IL-6, compared to moderate conditions (Chen et al., 2020; Ramanathan 
et al., 2020). Furthermore, through postmortem examination of the lung organ from COVID-19 patient, sign of acute respiratory distress syndrome (ARDS) and lymphocyte T-cells overactivation was shown. This condition can lead to high and uncontrollable cytotoxity of the T-cells against its host (Tang et al., 2020; Xu Z, Shi L, Wang Y, 2020).

SARS-CoV-2 virus is very small in size, which ranges from 60 to $100 \mathrm{~nm}$, it has round or slightly oval shape, and sheathed. It also has a single-chain RNA with 29.9 $\mathrm{kb}$, and can live in conditions of 5 to $11{ }^{\circ} \mathrm{C}$ and 47 to $79 \%$ humidity ratio. However, this virus can be inactivated by using UV light or heating to $56^{\circ} \mathrm{C}$ for 30 minutes and is also sensitive to disinfectants such as $75 \%$ ethanol (Lotfi et al., 2020; Zhu et al., 2020). In addition, the SARS-CoV-2 virus also has a high rate of mutation and recombinant, allowing the virus to mutate rapidly after being transmitted from one individual to another (Sheikhzadeh et al., 2020). This condition becomes an obstacle as well as a challenge for researchers to discover and develop specific drugs or vaccines for SARS-CoV-2 virus. Until now, several steps have been taken by the researchers including drug repurposing, and after some drugs are discovered to have potential as antiCOVID-19, those candidates were developed into more effective and safer pharmaceutical dosage forms than the marketed products.

\section{DRUG REPURPOSING}

The process of discovering and developing new drugs until being approved by the drug regulatory agencies such as the Food and Drug Administration (FDA) may take a long time, around 10 to 15 years, and requires a lot of expenses (Parvathaneni et al., 2019). Especially in the current COVID-19 pandemic, classical drug discovery approaches are not preferable since there is an urgent need of drugs and vaccines that are effective for SARSCoV-2 virus. Therefore, researchers began to shift from classical approaches to drug repurposing approaches as an alternative to drug discovery and development.

Drug repurposing, also known as drug repositioning, drug reprofiling or drug re-tasking, is a strategy for discovering, researching and developing new therapeutic indications for drugs besides the indication that has been approved by the drug regulatory agencies. The advantage of the drug repurposing approach is that it shortens the duration of drug discovery and development process because the safety profile of the drug which being studied was known so that the phase 1 in clinical trials can be skipped. In addition, drug repurposing can also reduce the costs required in its process and has lesser risk in the research (Agrawal, 2015; Parvathaneni et al., 2019; Zhou et al., 2020).
The ideal anti-COVID-19 drug strategy is through 3 mechanisms. First, by targeting the Angiotensin Converting Enzyme 2 (ACE-2) receptor, which is the receptor used by the SARS-CoV-2 virus to infect the host. When the drug binds to the ACE- 2 receptor, the SARS-CoV-2 virus will not be able to bind to the ACE2 receptor and infection can be avoided. The second mechanism is by targeting the Receptor Binding Domain (RBD) on the spike protein of SARS-CoV-2 virus, thus when the drug binds to the RBD of the SARS-CoV-2 virus, the virus cannot bind to the ACE- 2 receptor and the infection will also be avoided. The third mechanism is by targeting the main protease $\left(\mathrm{M}^{\mathrm{pro}}\right)$ enzyme, which plays an important role in viral transcription and replication. When the drug is designed to inhibit the $\mathrm{M}^{\text {pro }}$ enzyme, the drug will prevent the process of viral transcription and replication and eventually kill the virus (Zhu et al., 2020). Until now, many drugs have been studied for antiCOVID-19 activity. Here are some examples of drugs that have been studied and show potential activities as anti-COVID-19.

\section{Remdesivir}

Remdesivir is an adenosine nitrogen base analogue compound that forms nucleosides. Initially, remdesivir or GS-5734 was used as an antiviral drug for ebola virus which attacked West Africa. Remdesivir also turned out to be a prodrug, therefore when remdesivir is used, it will undergo a metabolism process and becomes its active metabolite called GS-441524 which has a role as a competitive inhibitor to the dependent RNA enzyme - RNA polymerase (RdRp) so that the synthesis and replication of viral RNA process can be inhibited (Frediansyah et al., 2020; Warren et al., 2016). In an invitro test of the anti-COVID-19 activity from remdesivir, satisfying results were obtained, where remdesivir effectively inhibits SARS-CoV-2 infection on Vero E6 cells by $90 \%$ at concentrations of $1.76 \mu \mathrm{M}$ (Wang et al., 2020).

Trial on remdesivir as an anti-COVID-19 drug has also gone through the preclinical testing phase. In one study, remdesivir was administered at a dose of $10 \mathrm{mg} /$ $\mathrm{kg}$ BW intravenously to rhesus macaques that had been infected with the SARS-CoV-2 virus. After 12 hours, remdesivir was given orally at a dose of $5 \mathrm{mg} / \mathrm{kgBW}$ for 7 days. Subsequently, the level of damage of lung organ histopathologically and the number of infectious viruses after treatment were evaluated. The results obtained showed that the remdesivir-treated group did not show any sign of lung damage and the number of virus titre in bronchoalveolar lavage was also found to decrease about 100 fold lower than the controls group after 12 hours and no longer detected after 3 days (Williamson et al., 2020). Clinical trial of remdesivir has also been carried out on 53 COVID-19 patients from January to March 2020 in 
a hospital in New England. The patients were given 200 $\mathrm{mg}$ of remdesivir intravenously on the first day, followed by $100 \mathrm{mg}$ daily for 9 days. The results showed that 36 out of 53 patients (about 68\%) had improvement of clinical quality of life (Grein et al., 2020).

\section{Chloroquine / Hydroxychloroquine}

Chloroquine is a derivate from quinoline compound that has a chlorine group at position 7 and a 4-diethylamino1-methylbutylamino group at position 4 from quinoline (White et al., 2020). Chloroquine and its analogue, hydroxychloroquine, were originally developed in 1934 and were commonly used as antimalarial drugs and there are also studies concluding that hydroxychloroquine can be used for systemic lupus erythematosus treatment (Giaime et al., 2020; Jallouli et al., 2015). Currently, chloroquine and hydroxychloroquine have been studied through drug repurposing and have been used as drugs in the therapy of COVID-19 patients. Chloroquine and hydroxychloroquine can act as antiviral agents for COVID-19 by suppressing cytokine storms. The mechanism occurs in 2 ways, the first is because chloroquine and hydroxychloroquine are weak bases, therefore can increase the $\mathrm{pH}$ of the endosome which modulates toll-like receptor (TLR) signaling process which leads to suppression of production of proinflammatory cytokines such as Tumor Necrosis Factor (TNF), interleukin-6 (IL-6) and IL-1, while the second route is through an increase in lysosome $\mathrm{pH}$ which results in reduced $\mathrm{T}$ cell production so that cytokine storms can be avoided (Tripathy et al., 2020).

Results of an in-vitro study showed that hydroxychloroquine has better potential than chloroquine as an anti-COVID-19 drug, which were tested on Vero E6 cells with an EC50 concentration of $0.72 \mu \mathrm{M}$ for hydroxychloroquine and $5.47 \mu \mathrm{M}$ for chloroquine (Yao et al., 2020). A clinical trial was conducted on 36 COVID-19 patients at The Mediterranee Infection University Hospital Institute in Marseille, France by administering hydroxychloroquine sulfate $200 \mathrm{mg} 3$ times daily for 10 days orally. The results obtained showed that $70 \%$ of patients experienced virological recovery (Gautret et al., 2020).

\footnotetext{
Azithromycin

Azithromycin is a macrolide antibiotic that has a macrocyclic lactone ring. Initially azithromycin was used as a bacteriostatic drug to Gram positive bacteria which infects the respiratory tract (Giaime et al., 2020; Pani et al., 2020). Interestingly, after several studies, it was found that azithromycin can also act as immunomodulator and regulates inflammatory responses, increases immunoglobulin production and suppresses the production of cytokines such as TNF- $\alpha$, IL-6, and IL-8, so that the cytokine storm reactions
}

can be avoided (Pani et al., 2020; Rizk et al., 2020; Zarogoulidis et al., 2012). Other studies showed that azithromycin also has antiviral activity against zika virus and rhinovirus through the induction of interferons production (Retallack et al., 2016; Schögler et al., 2015).

The investigation of azithromycin activity as an antiCOVID-19 drug has been carried out on Vero E6 cells. Results showed that azitrhomycin is one of the drugs that has the potential to be anti-COVID-19 drug, with $\mathrm{EC}_{50}$ value of $2.12 \mu \mathrm{M}$ (Touret et al., 2020). The ability of azithromycin as an anti-COVID-19 drug combined with hydroxychloroquine has been clinically tested. The study was conducted by giving $600 \mathrm{mg}$ hydroxychloroquine and $500 \mathrm{mg}$ azithromycin on the first day and $250 \mathrm{mg}$ once daily for 4 days. The results showed that when hydroxychloroquine and azitrhomycin were combined, effectivity can be increased compared to single hydroxychloroquine therapy, where on the fifth day the combination group showed negative results from PCR test (Gautret et al., 2020). Another study recommends to use an initial adult dose of $500 \mathrm{mg}$ followed by 250 $\mathrm{mg}$ once daily for 4 days, and $10 \mathrm{mg} / \mathrm{kg}$ on the first day followed by $5 \mathrm{mg} / \mathrm{kg}$ for 4 days after, for children under 18 years old (Schwartz \& Suskind, 2020).

\section{Corticosteroid}

Corticosteroids are steroid hormone compounds that can be divided into mineralocorticoids and glucocorticoids. Generally, the term corticosteroid refers to the glucocorticoid group (Ramamoorthy et al., 2017). Corticosteroid was originally used as an antiinflammatory drug, although later shown to have an immuosupressive effect as well. Because of that, corticosteroids could be an alternative to reduce the infection of SARS-CoV-2 virus. The mechanism is through suppression of proinflammatory cytokine production (Ahmed \& Hassan, 2020). One of the corticosteroids that is often used in therapy is dexamethasone.

Clinical studies regarding the ability of dexamethasone as anti-COVID-19 have been investigated. The study was conducted by giving dexamethasone to infected patients, either orally or intravenously (at random) at a dose of $6 \mathrm{mg}$ per day for 10 days. Afterwards, the mortality rate after 28 days was evaluated. The results obtained indicate that by using dexamethasone the mortality rate can be reduced by $12.3 \%$ in patients using invasive mechanical ventilation devices and $4.2 \%$ in patients using oxygen alone (Horby et al., 2020).

\section{Other Potential Drugs}

\section{Statins}

Statins were originally used to inhibit sterol synthesis pathway which can lead to lower concentration 
Table 1. Repurposed drug as anti-covid-19 and their dosage forms development

\begin{tabular}{|c|c|c|c|c|c|c|}
\hline Drug & Original Use & & $\begin{array}{l}\text { A n t i - C O V I D - } 19 \\
\text { Mechanism }\end{array}$ & Results & Development of Dosage Forms & References \\
\hline Remdesivir & $\begin{array}{l}\text { Antiviral for } \\
\text { Virus }\end{array}$ & Ebola & $\begin{array}{l}\text { Metabolized into its } \\
\text { active form called } \\
\text { "GS-441524" r and } \\
\text { subsequently inhibits } \\
\text { the dependent RNA } \\
\text { enzyme - RNA } \\
\text { polymerase (RdRp) } \\
\text { competitively therefore } \\
\text { the synthesis and } \\
\text { replication of viral } \\
\text { RNA process can be } \\
\text { inhibited }\end{array}$ & $\begin{array}{l}\text { In-Vitro: } \\
\text { Remdesivir effectively inhibits SARS- } \\
\text { CoV-2 infection on Vero E6 cells by } 90 \% \text { at } \\
\text { concentrations of } 1.76 \mu \mathrm{M} \text {. } \\
\text { In-Vivo: } \\
\text { Remdesivir was administered at a dose of } 10 \\
\text { mg/kg BW intravenously to infected rhesus } \\
\text { macaques for the first } 12 \text { hours and orally at a } \\
\text { dose of } 5 \mathrm{mg} / \mathrm{kgBW} \text { for } 7 \text { days. The results } \\
\text { did not show any sign of lung damage and the } \\
\text { number of virus titre in bronchoalveolar lavage } \\
\text { was } 100 \text { fold lower than the control group after } \\
12 \text { hours and no longer detected after } 3 \text { days } \\
\text { Clinical Trial: } \\
53 \text { patients were given } 200 \text { mg of remdesivir } \\
\text { intravenously on the first day, followed by } 100 \\
\text { mg daily for } 9 \text { days. The results showed that } 36 \\
\text { out of } 53 \text { patients (about } 68 \% \text { ) had improvement } \\
\text { of clinical quality of life. On the other hand, } 32 \\
\text { of } 36 \text { subjects ( } 60 \% \text { ) who received remdesivir } \\
\text { intravenously had at least one side effect and } \\
12 \text { subjects ( } 23 \% \text { ) had a serious side effect. The } \\
\text { side effects that often occur are diarrhea, organ } \\
\text { dysfunction syndrome (septic shock), acute } \\
\text { kidney damage, and hypotension }\end{array}$ & $\begin{array}{l}\text { Dry Powder Inhalation: } \\
\text { The dry powder was made by } \\
\text { thin film freezing method and } \\
\text { used leucine as the excipient and } \\
\text { acetonitrile:water (50:50) as the } \\
\text { solvent. } \\
\text { The result from the evaluation of } \\
\text { the dry powder showed satisfying } \\
\text { aerodynamic characteristics } \\
\text { as indicated by } 89-92 \% \text { of } \\
\text { the particle fractions that were } \\
\text { successfully sprayed }\end{array}$ & $\begin{array}{l}\text { Frediansyah et al., } \\
2020 \text {; } \\
\text { Grein et al., 2020; } \\
\text { Sahakijpijarn et al., } \\
\text { 2020; Wang et al., } \\
2020 \text {; } \\
\text { Warren et al., 2016; } \\
\text { Williamson et al., } \\
2020\end{array}$ \\
\hline
\end{tabular}


Table 1. continued

\begin{tabular}{|c|c|c|c|c|c|}
\hline Drug & Original Use & $\begin{array}{l}\text { A n t i - C O V I D - } 19 \\
\text { Mechanism }\end{array}$ & Results & Development of Dosage Forms & References \\
\hline $\begin{array}{l}\text { Chloroquine/ } \\
\text { Hydroxychloro- } \\
\text { quine }\end{array}$ & Antimalaria & $\begin{array}{l}\text { The mechanism occurs } \\
\text { in } 2 \text { ways: } \\
\text { 1. Chloroquine/ hy- } \\
\text { droxychloroquine } \\
\text { increase the pH } \\
\text { of the endosome } \\
\text { which modulates } \\
\text { TLR signaling } \\
\text { process which } \\
\text { leads to suppres- } \\
\text { sion of production } \\
\text { of pro-inflamma- } \\
\text { tory cytokines } \\
\text { such as TNF, IL-6 } \\
\text { and IL-1 } \\
\text { Chlor o q i i e / } \\
\text { h y d r o x y - } \\
\text { c h l o r o q u i n e } \\
\text { increases the } \\
\text { lysosome pH } \\
\text { which results in } \\
\text { reduced T cell } \\
\text { production so the } \\
\text { cytokine storms } \\
\text { can be avoided }\end{array}$ & $\begin{array}{l}\text { In-Vitro: } \\
\text { Both hydroxychloroquine and chloroquine have } \\
\mathrm{EC}_{50} \text { concentration of } 0.72 \mu \mathrm{M} \text { and } 5.47 \mu \mathrm{M} \text {, } \\
\text { respectively, which can inhibit SARS-CoV-2 } \\
\text { infection on Vero E6 cells. } \\
\text { Clinical Trial: } \\
36 \text { COVID- } 19 \text { patients were administered } \\
\text { orally with hydroxychloroquine sulfate } 200 \mathrm{mg} \\
3 \text { times daily for } 10 \text { days. The results showed } \\
\text { that } 25 \text { of } 36 \text { patients (about } 70 \% \text { ) experienced } \\
\text { virological recovery }\end{array}$ & $\begin{array}{l}\text { Liposomal hydrochloroquine: } \\
\text { The liposome was made with } \\
\text { DPPC and cholesterol. This } \\
\text { liposome is administered through } \\
\text { inhalation route. The result of pre- } \\
\text { clinical trial on rats shows that } \\
\text { AUC and } \mathrm{t}_{1 / 2} \text { were greater than } \\
\text { intravenous route, indicating that } \\
\text { the penetration ability is increased } \\
\text { with extended residence time. The } \\
\text { liposomal hydroxychloroquine } \\
\text { also has higher maximum } \\
\text { concentration in lung than in } \\
\text { heart and blood plasma. It shows } \\
\text { that the delivery of liposomal } \\
\text { hydroxychloroquine via inhalation } \\
\text { route has a local effect in the lung } \\
\text { tissue. }\end{array}$ & $\begin{array}{l}\text { Gautret et al., 2020; } \\
\text { Tai et al., 2020; } \\
\text { Tripathy et al., 2020; } \\
\text { Yao et al., 2020 }\end{array}$ \\
\hline
\end{tabular}


Table 1. continued

\begin{tabular}{|c|c|c|c|c|c|}
\hline Drug & Original Use & $\begin{array}{l}\text { An ti - C O V I D - } 19 \\
\text { Mechanism }\end{array}$ & Results & Development of Dosage Forms & References \\
\hline Azithromycin & Antibiotic & $\begin{array}{l}\text { A } \mathrm{z} \text { i } \mathrm{t} \mathrm{h} \mathrm{r} \text { o } \mathrm{m} \mathrm{y} \mathrm{c} \mathrm{i} \mathrm{n} \\
\text { regulates inflammatory } \\
\text { responses by increasing } \\
\text { i m m u o g l o b u li } \mathrm{n} \\
\text { production and } \\
\text { suppressing the } \\
\text { production of } \\
\text { cytokines such as } \\
\text { TNF- } \alpha \text {, IL-6, and IL- } \\
8 \text {, so that the cytokine } \\
\text { storm reactions can be } \\
\text { avoided }\end{array}$ & $\begin{array}{l}\text { In-vitro: } \\
\text { The } \mathrm{EC}_{50} \text { value of azithromycin is } 2.12 \mu \mathrm{M} \text { in } \\
\text { inhibiting the infection of SARS-CoV-2 to Vero } \\
\text { E6 cells. } \\
\text { Clinical Trial: } \\
500 \mathrm{mg} \text { azithromycin combined with } 600 \mathrm{mg} \\
\text { hydroxychloroquine on the first day and after } \\
\text { that azithromycin } 250 \mathrm{mg} \text { was used once } \\
\text { daily for } 4 \text { days. The result showed that the } \\
\text { combination group showed negative results } \\
\text { from PCR results on the fifth day }\end{array}$ & & $\begin{array}{l}\text { Gautret et al., 2020; } \\
\text { Pani et al., 2020; } \\
\text { Touret et al., 2020; } \\
\text { Zarogoulidis et al., } \\
2012\end{array}$ \\
\hline $\begin{array}{l}\text { Corticosteroid } \\
\text { (Dexamethasone) }\end{array}$ & Antiinflammatory & $\begin{array}{l}\text { Corticosteroid can } \\
\text { suppress the pro- } \\
\text { inflammatory cytokine } \\
\text { production, so the } \\
\text { cytokine storm reaction } \\
\text { could be avoided }\end{array}$ & $\begin{array}{l}\text { Clinical trial: } \\
\text { Dexamethasone was administered to COVID- } 19 \\
\text { patients either orally or intravenously at a dose } \\
\text { of } 6 \mathrm{mg} \text { per day for } 10 \text { days. After } 28 \text { days, } \\
\text { evaluation of mortality rate was performed. The } \\
\text { result obtained indicates that dexamethasone } \\
\text { can reduce the mortality rate by } 12.3 \% \text { in } \\
\text { patients using invasive mechanical ventilation } \\
\text { devices and } 4.2 \% \text { in patients using oxygen alone }\end{array}$ & $\begin{array}{l}\text { Dexamethasone-loaded leukosomes: } \\
\text { The dexamethasone-loaded } \\
\text { leukosome was made by loading } \\
\text { the dexamethasone-cyclodextrin } \\
\text { complex into the leucocyte } \\
\text { vesicles made of DPPC:DOPC: } \\
\text { cholesterol ( } 4: 3: 3) \text { and mixed with } \\
\text { the J774 macrophage membrane. } \\
\text { The result of preclinical trial } \\
\text { on mice shows that compared } \\
\text { to dexamethasone alone, } \\
\text { dexamethasone-loaded leukosome } \\
\text { had better activity in suppressing } \\
\text { the production of all tested pro- } \\
\text { inflammatory cytokines }\end{array}$ & $\begin{array}{l}\text { Ahmed \& Hassan, } \\
\text { 2020; Horby et al., } \\
\text { 2020; Molinaro etal., } \\
\text { 2020; Ramamoorthy } \\
\text { et al., } 2017\end{array}$ \\
\hline
\end{tabular}


Table 1. continued

\begin{tabular}{|c|c|c|c|c|c|}
\hline Drug & Original Use & $\begin{array}{l}\text { A n t i - C O V I D - } 19 \\
\text { Mechanism }\end{array}$ & Results & Development of Dosage Forms & References \\
\hline Statins & Anti-hyperlipidemia & $\begin{array}{l}\text { Statins } \\
\text { the production of } \\
\text { cytokines, especially } \\
\text { IL-6 }\end{array}$ & $\begin{array}{l}\text { Meta analysis: } \\
\text { There is a reduction in fatal or severe disease } \\
\text { by } 30 \% \text { with the use of statins in COVID- } 19 \\
\text { patients }\end{array}$ & & $\begin{array}{l}\text { Sirtori, 2014; } \\
\text { Dashti-Khavidaki } \\
\& \quad \text { Khalili, 2020; } \\
\text { Troeman etal., 2013; } \\
\text { Kow \& Hasan, 2020 }\end{array}$ \\
\hline Vitamin C & Antioxidant & $\begin{array}{l}\text { Vitamin C regulates } \\
\text { of pro-inflammatory } \\
\text { cytokine production, } \\
\text { so that cytokine storms } \\
\text { reaction can be avoided }\end{array}$ & & & $\begin{array}{l}\text { De Melo \& Homem- } \\
\text { De-Mello, } 2020\end{array}$ \\
\hline ACEi & Antihypertension & $\begin{array}{l}\text { ACEi inhibits the virus } \\
\text { to bind to the ACE } 2 \\
\text { receptor, therefore } \\
\text { the infection can be } \\
\text { avoided }\end{array}$ & $\begin{array}{l}\text { Clinical trial: } \\
12,549 \text { patients were tested for COVID-19 in } \\
\text { New York, } 5,894(46.8 \%) \text { from these patients } \\
\text { were found positive, } 1,002 \quad(17 \%) \text { from } \\
\text { these patients had severe illness. A history } \\
\text { of hypertension was present in } 4,357 \text { patients } \\
(34.6 \%) \text {, among them } 2,573(59.1 \%) \text { had } \\
\text { positive test results, and the remaining patients } \\
\text { had severe illness of COVID-19. There was no } \\
\text { association between ACEi or ARB medication } \\
\text { and there is no increased likelihood of positive } \\
\text { results }\end{array}$ & & $\begin{array}{l}\mathrm{Lu} \text { et al., 2020; } \\
\text { Reynolds et al., } \\
2020\end{array}$ \\
\hline
\end{tabular}


Table 1. continued

\begin{tabular}{|c|c|c|c|c|c|}
\hline Drug & Original Use & $\begin{array}{l}\text { A n t i - C O V I D - } 19 \\
\text { Mechanism }\end{array}$ & Results & Development of Dosage Forms & References \\
\hline Colchicine & Antiinflammatory & $\begin{array}{l}\text { Colchicine suppresses } \\
\text { the caspase-1 } \\
\text { activation and also } \\
\text { inhibits the production } \\
\text { of inflammatory } \\
\text { cytokines, such as IL- } \\
1 \beta \text { and IL-18 }\end{array}$ & $\begin{array}{l}4,488 \text { patients were administered orally with } \\
\text { colchicine } 0.5 \mathrm{mg} \text { twice daily for the first } 3 \\
\text { days and subsequently once daily for } 27 \text { days. } \\
\text { The result showed that even though it is not } \\
\text { significant but there was a reduction in mortality } \\
\text { rate about } 0.1 \%\end{array}$ & & $\begin{array}{l}\text { Schlesinger et al., } \\
2020 ; \text { Gendelman } \\
\text { et al., 2020; Parra- } \\
\text { medina et al., 2020; } \\
\text { Tardif et al., 2021 }\end{array}$ \\
\hline Nitazoxanide & Antiparasitic & $\begin{array}{l}\text { Nitazoxanide inhibits } \\
\text { the expression of } \\
\text { the viral } \mathrm{N} \text { protein } \\
\text { and potentiates } \\
\text { the production of } \\
\text { interferon- } \alpha \text { and } \\
\text { interferon- } \beta\end{array}$ & $\begin{array}{l}\text { In-vitro: } \\
\text { Nitazoxanide could inhibit SARS-CoV-2 virus } \\
\text { in Vero E6 cells with } \mathrm{EC}_{50} \text { concentration of } 2.12 \\
\mu \mathrm{M}\end{array}$ & & $\begin{array}{l}\text { Mahmoud et al., } \\
\text { 2020; Cao et al., } \\
\text { 2020; Rossignol, } \\
\text { 2016; Wang et al., } \\
2020\end{array}$ \\
\hline
\end{tabular}


of cholesterol in blood and also used to prevent cardiovascular diseases (Sirtori, 2014). Besides their role as inhibitors to prevent any cardiovacular disease, statins are also reported to have a role in modulating the immune response against COVID-19. Through several studies, statins have been shown to decrease inflammation, decrease the production of cytokines, especially IL-6, and decrease lung injury (DashtiKhavidaki \& Khalili, 2020; Troeman et al., 2013). A study about anti-COVID-19 activity of several statins has been performed in-silico, and the results showed that the binding affinities of pitavastatin, rosuvastatin, lovastatin, and fluvastatin with main protease of SARS-CoV-2 virus (PDB ID: 6LU7) are -8.2, -7.7, -7.4, and $7.7 \mathrm{kcal} / \mathrm{mol}$, respectively. Therefore, it can be indicated that statins could be efficient SARS-CoV-2 Mpro inhibitors (Reiner et al., 2020). A meta-analysis from four studies about the effect of statins in patient with COVID-19 also suggested a reduction in fatal or severe disease by $30 \%$ with the use of statins in COVID-19 patients (Kow \& Hasan, 2020). From these studies, it can be concluded that statins can be a complementary therapy for COVID- 19 .

\section{Vitamin C}

Vitamin $C$ is a water-soluble vitamin and is known to have excellent antioxidant properties. Besides its antioxidant abilities, vitamin $\mathrm{C}$ also plays a role in regulating the immune system and is also able to provide protection against viral infections, including SARSCoV-2 virus (Junaid et al., 2020). Therefore, vitamin $\mathrm{C}$ has the potential to be one of the anti-COVID-19 therapies. A possible anti-COVID-19 mechanism of vitamin $\mathrm{C}$ is through regulation of pro-inflammatory cytokine production, so that cytokine storms reaction can be avoided (De Melo \& Homem-De-Mello, 2020). However, informations regarding the effectiveness of vitamin $\mathrm{C}$ as an anti-COVID-19 through in-vitro study, in-vivo study and clinical trials are still not available, therefore further research is still required.

\section{Angiotensin Converting Enzyme Inhibitors (ACEi)}

ACE2 is an enzyme responsible in converting angiotensin I into angiotensin II in lungs. ACE2 receptors are the entry point for SARS-CoV-2 virus to infect humans. If the receptors were bound with ACEi drugs, the virus will not be able to bind with the receptor anymore and the infection might be avoided. ACEi was originally used as antihypertension ( $\mathrm{Lu}$ et al., 2020). An observational study analyzed 12,549 patients who were tested for COVID-19 in New York, with 5,894 (46.8\%) patients were found positive and 1,002 (17\%) patients had severe illness. A history of hypertension was present in 4,357 patients (34.6\%), among them 2,573 (59.1\%) had positive test results, while others had severe illness of COVID-19. There was no association between ACEi or ARB medication and there is no increased likelihood of positive COVID-19 tests (Reynolds et al., 2020). A metaanalysis about the association of treatment with ACEi or ARB and risk of severe/lethal COVID-19 strongly suggests and supports the recommendation to continue ARB or ACEi for all patients, unless otherwise advised by their physicians who should thus be reassured (Flacco et al., 2020).

\section{Colchicine}

Colchicine is an alkaloid compound and initially was isolated from meadow saffron (Colchicum autumnale). Colchicine has been commonly used as antiinflammatory for gout treatment (Schlesinger et al., 2020). This antiinflammatory effect is exhibited by suppressing caspase-1 activation and also by inhibiting the production of inflammatory cytokines, such as IL$1 \beta$ and IL-18 (Gendelman et al., 2020; Parra-medina et al., 2020). Through this mechanism, colchicine might play an important role in preventing the cytokine storm. A retrospective study on 14,520 COVID-19 patients in Israel found no significant difference in mortality rate of colchicine use between patients with positive and negative RT-PCR results for SARS-CoV-2, which is $0.53 \%$ versus $0.48 \%$. These results suggest that colchicine might not have a protective role against SARS-CoV-2 virus' infection (Gendelman et al., 2020). However, a clinical trial aimed to investigate the ability of colchicine in reducing mortality rate of unhospitalized COVID-19 patients has been performed on 4,488 patients by administering them orally with colchicine $0.5 \mathrm{mg}$ twice daily for the first 3 days and subsequently once daily for 27 days after. The result showed that even though it is not significant but there was a reduction in mortality rate about $0.1 \%$ (Tardif et al., 2021). In order to have a certainty about colchicine activity against COVID-19, further research is required.

\section{Nitazoxanide}

Nitazoxanide was approved by FDA as an antiparasitic drug for diarrhea and enteritis triggered by Cryptosporidium spp. since 2002 (Mahmoud et al., 2020). Through in-vitro studies, it was known that nitazoxanide also has an antiviral activity against coronavirus by inhibiting the expression of the viral $\mathrm{N}$ protein, which is the nucleocapsid of the virus, and nitazoxanide is also known to potentiate the production of interferon- $\alpha$ and interferon- $\beta$ (Cao et al., 2020; Rossignol, 2016). It has been hypothesized that nitazoxanide also has similar mechanism against SARS-CoV-Virus. Wang et al. (2020) have reported that nitazoxanide could inhibit SARS-CoV-2 virus in Vero E6 cells with $\mathrm{EC}_{50}$ concentration of $2.12 \mu \mathrm{M}$. A clinical trial suggested that using the combination of nitazoxanide and azithromycin as a protocol for early stage of COVID-19 infection might be safer and more effective than the combination of hydroxychloroquine and azithromycin, although 
further research to ensure this suggestion is still required (Kelleni, 2020).

\section{NEW DEVELOPMENT OF DOSAGE FORMS OF ANTI-COVID-19 DRUGS}

During this pandemic, many studies on drug repurposing have been carried out. However, one of the biggest obstacles in the treatment or therapy of COVID-19 today is the lack of effectiveness and safety of the drugs, including the adverse effects that can occur during therapy (Cavalcanti \& Cajubá de Britto Lira Nogueira, 2020). Therefore, it is necessary to develop drugs that are known to have potential and activity as anti-COVID-19 through drug repurposing so that the treatment or therapy can be more effective and the drug's adverse effects can be minimized. Here are some examples of anti-COVID-19 drugs that have been developed:

\section{Dry Powder Inhalation Remdesivir}

Sahakijpijarn et al. (2020) have conducted research to develop remdesivir into a dry powder for inhalation dosage form. Based on a previous clinical study of remdesivir, it was found that 32 of 36 subjects $(60 \%)$ who received remdesivir intravenously had at least one side effect and 12 subjects (23\%) had a serious side effect. The side effects include diarrhea, organ dysfunction syndrome (septic shock), acute kidney damage, and hypotension (Grein et al., 2020). Therefore, remdesivir was developed into a dry powder for inhalation dosage form, because the inhalation route of drug delivery can provide several benefits, such as avoiding first-pass metabolism of drugs, increasing the potential of drugs locally in the lungs, and reducing the systemic drug side effects. The method used in formulating the dry powder dosage form was thin film freezing, which involves freezing on the mixed solution and turning it into a thin film layer, followed by lyophilizing it to produce a dry powder. The evaluation results of the dry powder indicated that the dosage form using leucine as their excipient had satisfying aerodynamic characteristics as indicated by $89-92 \%$ of the particle fractions that were successfully sprayed (Sahakijpijarn et al., 2020). However, information regarding the effectiveness and safety of the developed remdesivir into dry powder for in-vivo studies and clinical trials are still not available, making it necessary to test the effectiveness of this developed dosage form so that the efficacy and safety of this dosage form could be more assured.

\section{Dexamethasone-Loaded Leukosomes}

Molinaro etal.(2020) havealso developed dexamethasone into nanoparticles called leukosomes. Leukosome is a nanovesicle that is developed with characteristics resembling leukocytes, so that the cleaning by the mononuclear phagocytic system can be avoided and the drug delivery system can be modified to be targeted delivery system. The dexamethasone-loaded leukosome was formulated by loading the dexamethasonecyclodextrin complex into the leucocyte vesicles made of dipalmitoylphosphatidylcholine (DPPC), dioleoylphosphatidylcholine (DOPC) and cholesterol in a ratio of 4:3:3 and mixed with the J774 macrophage membrane. The dexamethasone-loaded leukosome obtained has an average particle size of $120 \mathrm{~nm}$ with a polydispersity index below 0.1 , a zeta potential of $-14 \mathrm{mV}$ and $75 \%$ of the dexamethasone loaded in the leukosome. Based on the drug release test, it was shown that $75 \%$ dexamethasone was released from the leukosome system within 10 hours and reached $100 \%$ at 48 hours in phosphate buffer medium (PBS) at $37^{\circ} \mathrm{C}$. Afterwards, the activity on suppressing the pro-inflammatory cytokines production of dexamethasone leukosome was tested, including TNF- $\alpha$, IL-1 $\alpha$, IL-6, macrophage colony stimulating factor (M-CSF), circulating adhesion molecule-1 (ICAM-1), monocyte, chemotactic protein-1 (MCP1), B lymphocyte chemoattractant (BLC), CCL5 and complement components. Compared to dexamethasone, dexamethasone-loaded leukosome had better activity in suppressing the production of all tested pro-inflammatory cytokines (Molinaro et al., 2020), therefore dexamethasone-loaded leukosome can be one of the anti-COVID-19 drug candidates that can be developed and studied further.

\section{Liposomal Hydroxychloroquine}

Another study also conducts a development of hydroxychloroquine by loading it into liposomes. The reason for this development was due to the side effects caused by hydroxychloroquine, which were prolongation of the QT interval on heart rhythm and hydroxychloroquine is also cardiotoxic at high doses. Therefore, a liposome containing hydroxychloroquine was developed and delivered via inhalation route to avoid cardiotoxic and other systemic side effects. Liposome vesicles were made using dipalmitoilphosphatidylcholine (DPPC) and cholesterol. Based on in-vivo pharmacokinetic studies in mice, it was found that in the lung organs, inhaled hydroxychloroquine liposomes had maximum concentration, area under the curve and $t_{1 / 2}$ were greater than intravenous hydroxychloroquine and inhaled hydroxychloroquine. This indicates that the hydroxychloroquine loaded in the liposomes has an increasing ability to penetrate the lung tissue with extended residence time. Meanwhile, when viewed in different organs, the maximum concentration profile and area under the curve of the hydroxychloroquine liposomes in blood plasma and in the heart tissue are lower than in lung tissue. This indicates that the delivery of hydroxychloroquine liposomes via the inhalation route has a local effect in the lung tissue (Tai et al., 2020). However, information regarding clinical trials of 
inhaled liposomal hydroxychloroquine dosage form is still not available. Therefore, it is still necessary to carry out further research into the clinical trial stage so that the efficacy and safety of the dosage form can be assured.

\section{CONCLUSIONS}

The development of anti-COVID-19 drugs was currently performed through drug repurposing approach and pharmaceutical dosage forms development. However, the testing carried out on most of the newly developed drugs and pharmaceutical dosage forms were still limited to in-vitro and preclinical tests. Therefore, it is still necessary to carry out further testing even to the clinical testing stage so that the efficacy and the safety of the drugs can be assured.

\section{CONFLICT OF INTEREST}

There is no conflict of interest to disclose.

\section{REFERENCES}

Agrawal, P. (2015). Advantages and Challenges in Drug Re-Profiling. Journal of Pharmacovigilance, s2, 2-3. https://doi.org/10.4172/2329-6887.s2-e002

Ahmed, M. H., \& Hassan, A. (2020). Dexamethasone for the Treatment of Coronavirus Disease (COVID-19): a Review. SN comprehensive clinical medicine, 1-10.

Behrens, E. M., \& Koretzky, G. A. (2017). Review: Cytokine Storm Syndrome: Looking Toward the Precision Medicine Era. Arthritis and Rheumatology, 69(6), 1135-1143. https://doi.org/10.1002/art.40071

Cao, J., Forrest, J. C., \& Zhang, X. (2015). A screen of the NIH clinical collection smal molecule library identifies potential anti-coronavirus drugs. Antiviral research, 114(2015), 1-10. https://dx.doi.org/10.1016/j. antiviral.2014.11.010

Cavalcanti, I. D. L., \& Cajubá de Britto Lira Nogueira, M. (2020). Pharmaceutical nanotechnology: which products are been designed against COVID-19? Journal of Nanoparticle Research, 22(9). https://doi.org/10.1007/ s11051-020-05010-6

Channappanavar, R., \& Perlman, S. (2017). Pathogenic human coronavirus infections: causes and consequences of cytokine storm and immunopathology. Seminars in Immunopathology, 39(5), 529-539. https://doi. org/10.1007/s00281-017-0629-x

Chen, G., Wu, D., Guo, W., Cao, Y., Huang, D., Wang, H., Wang, T., Zhang, X., Chen, H., Yu, H., Zhang,
X., Zhang, M., Wu, S., Song, J., Chen, T., Han, M., Li, S., Luo, X., Zhao, J., \& Ning, Q. (2020). Clinical and immunological features of severe and moderate coronavirus disease 2019. The Journal of clinical investigation, 130(5), 2620-2629.

Dashti-Khavidaki, S., \& Khalili, H. (2020). Considerations for Statin Therapy in Patients with COVID-19. Pharmacotherapy, 40(5), 484-486. https:// doi.org/10.1002/phar.2397

De Melo, A. F., \& Homem-De-Mello, M. (2020). Highdose intravenous vitamin $\mathrm{C}$ may help in cytokine storm in severe SARS-CoV-2 infection. Critical Care, 24(1), 1-2. https://doi.org/10.1186/s13054-020-03228-3

Flacco, M. E., Acuti Martellucci, C., Bravi, F., Parruti, G., Cappadona, R., Mascitelli, A., Manfredini, R., Mantovani, L. G., \& Manzoli, L. (2020). Treatment with ACE inhibitors or ARBs and risk of severe/lethal COVID-19: A meta-analysis. Heart, 106(19), 15191524. https://doi.org/10.1136/heartjnl-2020-317336

Frediansyah, A., Nainu, F., Dhama, K., Mudatsir, M., \& Harapan, H. (2020). Remdesivir and its antiviral activity against COVID-19: A systematic review. Clinical Epidemiology and Global Health, July, 0-1. https://doi. org/10.1016/j.cegh.2020.07.011

Gautret, P., Lagier, J. C., Parola, P., Hoang, V. T., Meddeb, L., Mailhe, M., Doudier, B., Courjon, J., Giordanengo, V., Vieira, V. E., Tissot Dupont, H., Honoré, S., Colson, P., Chabrière, E., La Scola, B., Rolain, J. M., Brouqui, P., \& Raoult, D. (2020). Hydroxychloroquine and azithromycin as a treatment of COVID-19: results of an open-label non-randomized clinical trial. International Journal of Antimicrobial Agents, 56(1), 105949. https:// doi.org/10.1016/j.ijantimicag.2020.105949

Gendelman, O., Amital, H., Bragazzi, N. L., Watad, A., \& Chodick, G. (2020). Continuous hydroxychloroquine or colchicine therapy does not prevent infection with SARS-CoV-2: Insights from a large healthcare database analysis. Autoimmunity reviews, 102566.

Giaime, P., Guenoun, M., Pedinielli, N., Narbonne, H., Bergounioux, J. P., Solas, C., Guilhaumou, R., Sampol, J., Ollier, J., Sichez, H., Serveaux, M., Brunner, F., \& Bataille, S. (2020). Hydroxychloroquine and azithromycin tolerance in haemodialysis patients during COVID-19 infection. Nephrology Dialysis Transplantation, 35(8), 1346-1353. https://doi. org/10.1093/ndt/gfaa191

Grein, J., Ohmagari, N., Shin, D., Diaz, G., Asperges, E., Castagna, A., Feldt, T., Green, G., Green, M. L., Lescure, 
F.-X., Nicastri, E., Oda, R., Yo, K., Quiros-Roldan, E., Studemeister, A., Redinski, J., Ahmed, S., Bernett, J., Chelliah, D., ... Flanigan, T. (2020). Compassionate Use of Remdesivir for Patients with Severe COVID-19. New England Journal of Medicine, 382(24), 2327-2336. https://doi.org/10.1056/nejmoa2007016

Horby, P., Lim, W.S., Emberson, J.R., Mafharn, M., Bell, J.L., Linsell, L., Staplin, N., Brightling, C., Ustianowski, A., Elmahi, E., et al. (2020). Dexamethasone in Hospitalized Patients with COVID-19 - Preliminary Report. The New England Journal of Medicine 1-11. https://doi.org/10.1056/NEJMoa2021436

Hui, D. S., I Azhar, E., Madani, T. A., Ntoumi, F., Kock, R., Dar, O., Ippolito, G., Mchugh, T. D., Memish, Z. A., Drosten, C., Zumla, A., \& Petersen, E. (2020). The continuing 2019-nCoV epidemic threat of novel coronaviruses to global health - The latest 2019 novel coronavirus outbreak in Wuhan, China. International Journal of Infectious Diseases, 91(January), 264-266. https://doi.org/10.1016/j.ijid.2020.01.009

Jallouli, M., Galicier, L., Zahr, N., Aumaître, O., Francès, C., Le Guern, V., Lioté, F., Smail, A., Limal, N., Perard, L., Desmurs-Clavel, H., Le Thi Huong, D., Asli, B., Kahn, J. E., Pourrat, J., Sailler, L., Ackermann, F., Papo, T., Sacré, K., ... Costedoat-Chalumeau, N. (2015). Determinants of hydroxychloroquine blood concentration variations in systemic lupus erythematosus. Arthritis and Rheumatology, 67(8), 2176-2184. https:// doi.org/10.1002/art.39194

Junaid, K., Ejaz, H., Abdalla, A. E., Abosalif, K. O. A., Ullah, M. I., Yasmeen, H., Younas, S., Hamam, S. S. M., \& Rehman, A. (2020). Effective immune functions of micronutrients against sars-CoV-2. Nutrients, 12(10), 1-14. https://doi.org/10.3390/nu12102992

Kelleni, M.T. (2020). Nitazoxanide/azithromycin combination for COVID-19: A suggested new protocol for early management. Pharmacological Research, 157(2020), $104874 . \quad \mathrm{https}: / /$ doi. org/10.1016.j.phrs.2020.104874

Kow, C.S. \& Hasan, S.S. (2020). Meta-analysis of effect of statins in patients with COVID-19. The american journal of cardiology. (2020). 153-155. https://doi. org/10.1016/j.amjcard.2020.08.004

Lee, D. W., Gardner, R., Porter, D. L., Louis, C. U.,Ahmed, N., Jensen, M., Grupp, S. A., \& Mackall, C. L. (2015). Current concepts in the diagnosis and management of cytokine release syndrome. Blood, 124(2), 188-195.

Lotfi, M., Hamblin, M. R., \& Rezaei, N. (2020).
COVID-19: Transmission, prevention, and potential therapeutic opportunities. Clinica chimica acta, 508(January), 254-266.

Lu, R., Zhao, X., Li, J., Niu, P., Yang, B., Wu, H., Wang, W., Song, H., Huang, B., Zhu, N., Bi, Y., Ma, X., Zhan, F., Wang, L., Hu, T., Zhou, H., Hu, Z., Zhou, W., Zhao, L., ... Tan, W. (2020). Articles Genomic characterisation and epidemiology of 2019 novel coronavirus : implications for virus origins and receptor binding. The Lancet, 395(10224), 565-574. https://doi.org/10.1016/ S0140-6736(20)30251-8

Mahmoud, D. B., Shitu, Z., \& Mostafa, A. (2020). Drug repurposing of nitazoxanide: can it be an effective therapy for COVID-19? Journal of Genetic Engineering and Biotechnology, 18(1). https://doi.org/10.1186/ s43141-020-00055-5

Molinaro, R., Pasto, A., Taraballi, F., Giordano, F., Azzi, J. A., Tasciotti, E., \& Corbo, C. (2020). Biomimetic Nanoparticles Potentiate the Anti-Inflammatory Properties of Dexamethasone and Reduce the Cytokine Storm Syndrome: An Additional Weapon against COVID-19?. Nanomaterials, 10(11), 2301.

Pani, A., Lauriola, M., Romandini, A., \& Scaglione, F. (2020). Macrolides and viral infections: focus on azithromycin in COVID-19 pathology. International Journal of Antimicrobial Agents, 56(2), 106053. https:// doi.org/10.1016/j.ijantimicag.2020.106053

Parra-Medina, R., Sarmiento-Monroy, J. C., RojasVillarraga, A., Garavito, E., Montealegre-Gómez, G., \& Gómez-López, A. (2020). Colchicine as a possible therapeutic option in COVID-19 infection. Clinical Rheumatology, 39(8), 2485-2486.

Parvathaneni, V., Kulkarni, N. S., Muth, A., \& Gupta, V. (2019). Drug repurposing: a promising tool to accelerate the drug discovery process. Drug Discovery Today, 24(10), 2076-2085. https://doi.org/10.1016/j. drudis.2019.06.014

Ramamoorthy, S., \& Cidlowski, J. A. (2016). Corticosteroids: mechanisms of action in health and disease. Rheumatic Disease Clinics, 42(1), 15-31.

Ramanathan, K., Antognini, D., Combes, A., Paden, M., Zakhary, B., Ogino, M., Maclaren, G., \& Brodie, D. (2020). Clinical features of patients infected with 2019 novel coronavirus in Wuhan, China. The Lancet, 395(January), 497-506.

Reiner, Ž., Hatamipour, M., Banach, M., Pirro, M., Al-Rasadi, K., Jamialahmadi, T., Radenkovic, D., 
Montecucco, F., \& Sahebkar, A. (2020). Statins and the COVID-19 main protease: In silico evidence on direct interaction. Archives of Medical Science, 16(2), 490496. https://doi.org/10.5114/aoms.2020.94655

Retallack, H., Di Lullo, E., Arias, C., Knopp, K. A., Laurie, M. T., Sandoval-Espinosa, C., Leon, W. R. M., Krencik, R., Ullian, E. M., Spatazza, J., Pollen, A. A., Mandel-Brehm, C., Nowakowski, T. J., Kriegstein, A. R., \& De Risi, J. L. (2016). Zika virus cell tropism in the developing human brain and inhibition by azithromycin. Proceedings of the National Academy of Sciences of the United States of America, 113(50), 14408-14413. https://doi.org/10.1073/pnas.1618029113

Reynolds, H. R., Adhikari, S., Pulgarin, C., Troxel, A. B., Iturrate, E., Johnson, S. B., Hausvater, A., Newman, J. D., Berger, J. S., Bangalore, S., Katz, S. D., Fishman, G. I., Kunichoff, D., Chen, Y., Ogedegbe, G., \& Hochman, J. S. (2020). Renin-Angiotensin-Aldosterone System Inhibitors and Risk of COVID-19. New England Journal of Medicine, 382(25), 2441-2448. https://doi. org/10.1056/nejmoa2008975

Rizk, J. G., Kalantar-Zadeh, K., Mehra, M. R., Lavie, C. J., Rizk, Y., \& Forthal, D. N. (2020). PharmacoImmunomodulatory Therapy in COVID-19. Drugs, 80(13), 1267-1292. https://doi.org/10.1007/s40265020-01367-z

Rossignol, J. F. (2016). Nitazoxanide, a new drug candidate for the treatment of Middle East respiratory syndrome coronavirus. Journal of Infection and Public Health, 9(3), 227-230. https://doi.org/10.1016/j. jiph.2016.04.001

Sahakijpijarn, S., Moon, C., Koleng, J. J., Christensen, D. J., \& Williams, R. O. (2020). Development of remdesivir as a dry powder for inhalation by thin film freezing. Pharmaceutics, 12(11), 1-27. https://doi.org/10.3390/ pharmaceutics 12111002

Schlesinger, N., Firestein, B. L., \& Brunetti, L. (2020). Colchicine in COVID-19: an Old Drug, New Use. Current Pharmacology Reports, 6(4), 137-145. https:// doi.org/10.1007/s40495-020-00225-6

Schögler, A., Kopf, B. S., Edwards, M. R., Johnston, S. L., Casaulta, C., Kieninger, E., Jung, A., Moeller, A., Geiser, T., Regamey, N., \& Alves, M. P. (2015). Novel antiviral properties of azithromycin in cystic fibrosis airway epithelial cells. European Respiratory Journal, 45(2), 428-439. https://doi.org/10.1183/09031936.00102014

Schwartz, R. A., \& Suskind, R. M. (2020). Azithromycin and COVID-19: Prompt early use at first signs of this infection in adults and children, an approach worthy of consideration. Dermatologic Therapy, 33(4), 2-4. https://doi.org/10.1111/dth.13785

Sharma, A., Tiwari, S., Deb, M. K., \& Marty, J. L. (2020). Severe acute respiratory syndrome coronavirus-2 (SARS-CoV-2): a global pandemic and treatment strategies. International Journal of Antimicrobial Agents, 56(2), 106054. https://doi.org/10.1016/j. ijantimicag.2020.106054

Sheikhzadeh, E., Eissa, S., Ismail, A., \& Zourob, M. (2020). Diagnostic techniques for COVID-19 and new developments. Talanta, 220(July), 121392. https://doi. org/10.1016/j.talanta.2020.121392

Sirtori, C. R. (2014). The pharmacology of statins. Pharmacological Research, 88, 3-11. https://oi. org/10.1016/j.phrs.2014.03.002

Tai, T. T., Wu, T. J., Wu, H. D., Tsai, Y. C., Wang, H. T., Wang, A. M., ... \& Chen, Y. C. (2021). A Strategy to Treat COVID-19 Disease With Targeted Delivery of Inhalable Liposomal Hydroxychloroquine: A Preclinical Pharmacokinetic Study. Clinical and translational science, 14(1), 132-136.

Tang, Y., Liu, J., Zhang, D., Xu, Z., Ji, J., \& Wen, C. (2020). Cytokine Storm in COVID-19: The Current Evidence and Treatment Strategies. Frontiers in Immunology, 11(July), 1-13. https://doi.org/10.3389/ fimmu.2020.01708

Tardif, J. C., Bouabdallaoui, N., L'Allier, P. L., Gaudet, D., Shah, B., Pillinger, M. H., ... \& COLCORONA Investigators. (2021). Efficacy of colchicine in nonhospitalized patients with COVID-19. Medrxiv.

Touret, F., Gilles, M., Barral, K., Nougairède, A., van Helden, J., Decroly, E., de Lamballerie, X., \& Coutard, B. (2020). In vitro screening of a FDA approved chemical library reveals potential inhibitors of SARSCoV-2 replication. Scientific Reports, 10(1), 1-8. https:// doi.org/10.1038/s41598-020-70143-6

Tripathy, S., Dassarma, B., Roy, S., Chabalala, H., \& Matsabisa, M. G. (2020). A review on possible modes of action of chloroquine/hydroxychloroquine: repurposing against SAR-CoV-2 (COVID-19) pandemic. International journal of antimicrobial agents, 56(2), 106028.

Troeman, D. P. R., Postma, D. F., Van Werkhoven, C. H., \& Oosterheert, J. J. (2013). The immunomodulatory effects of statins in community-acquired pneumonia: A systematic review. Journal of Infection, 67(2), 93-101. 
https://doi.org/10.1016/j.jinf.2013.04.015

Wang, M., Cao, R., Zhang, L., Yang, X., Liu, J., Xu, M., Shi, Z., Hu, Z., Zhong, W., \& Xiao, G. (2020). Remdesivir and chloroquine effectively inhibit the recently emerged novel coronavirus (2019-nCoV) in vitro. Cell Research, 30(3), 269-271. https://doi.org/10.1038/s41422-0200282-0

Warren, T. K., Jordan, R., Lo, M. K., Ray, A. S., Mackman, R. L., Soloveva, V., Siegel, D., Perron, M., Bannister, R., Hui, H. C., Larson, N., Strickley, R., Wells, J., Stuthman, K. S., Van Tongeren, S. A., Garza, N. L., Donnelly, G., Shurtleff, A. C., Retterer, C. J., ... Bavari, S. (2016). Therapeutic efficacy of the small molecule GS-5734 against Ebola virus in rhesus monkeys. Nature, 531(7594), 381-385. https://doi.org/10.1038/ nature 17180

White, N. J., Watson, J.A., Hoglund, R. M., Chan, X. H. S., Cheah, P. Y., \& Tarning, J. (2020). COVID-19 prevention and treatment: A critical analysis of chloroquine and hydroxychloroquine clinical pharmacology. PLoS Medicine, 17(9), 1-24. https://doi.org/10.1371/journal. pmed.1003252

Williamson, B. N., Feldmann, F., Schwarz, B., MeadeWhite, K., Porter, D. P., Schulz, J., van Doremalen, N., Leighton, I., Yinda, C. K., Pérez-Pérez, L., Okumura, A., Lovaglio, J., Hanley, P. W., Saturday, G., Bosio, C. M., Anzick, S., Barbian, K., Cihlar, T., Martens, C., ... de Wit, E. (2020). Clinical benefit of remdesivir in rhesus macaques infected with SARS-CoV-2. Nature, 585(7824), 273-276. https://doi.org/10.1038/s41586020-2423-5

Xu, Z., Shi, L., Wang, Y., Zhang, J., Huang, L., Zhang, C., ... \& Wang, F. S. (2020). Pathological findings of COVID-19 associated with acute respiratory distress syndrome. The Lancet respiratory medicine, 8(4), 420422.
Yang, W., Dang, X., Wang, Q., Xu, M., Zhao, Q., Zhou, Y., Zhao, H., Wang, L., Xu, Y., Wang, J., Han, S., Wang, M., Pei, F., \& Wan, Y. (2020). Rapid Detection of SARSCoV-2 Using Reverse Transcription RT-LAMP Method. Health Evaluation and Promotion, 47(1), 248-250. https://doi.org/10.7143/jhep.47.248

Yao, X., Ye, F., Zhang, M., Cui, C., Huang, B., Niu, P., Liu, X., Zhao, L., Dong, E., Song, C., Zhan, S., Lu, R., Li, H., Tan, W., \& Liu, D. (2020). In vitro antiviral activity and projection of optimized dosing design of hydroxychloroquine for the treatment of severe acute respiratory syndrome coronavirus 2 (SARS-CoV-2). Clinical Infectious Diseases, 71(15), 732-739. https:// doi.org/10.1093/cid/ciaa237

Ye, Z. W., Yuan, S., Yuen, K. S., Fung, S. Y., Chan, C. P., \& Jin, D. Y. (2020). Zoonotic origins of human coronaviruses. International Journal of Biological Sciences, 16(10), 1686-1697. https://doi.org/10.7150/ ijbs. 45472

Zarogoulidis, P., Papanas, N., Kioumis, I., Chatzaki, E., Maltezos, E., \& Zarogoulidis, K. (2012). Macrolides: From in vitro anti-inflammatory and immunomodulatory properties to clinical practice in respiratory diseases. European Journal of Clinical Pharmacology, 68(5), 479-503. https://doi.org/10.1007/s00228-011-1161-x

Zhou, Y., Wang, F., Tang, J., Nussinov, R., \& Cheng, F. (2020). Artificial intelligence in COVID-19 drug repurposing. The Lancet Digital Health, 2(12), e667e676. https://doi.org/10.1016/s2589-7500(20)30192-8

Zhu, Y., Li, J., \& Pang, Z. (2020). Recent insights for the emerging COVID-19: Drug discovery, therapeutic options and vaccine development. Asian Journal of Pharmaceutical Sciences, $x x x x, 1-21$. https://doi. org/10.1016/j.ajps.2020.06.001 